\title{
Early Pregnancy Maternal Hepatocyte Growth Factor and Risk of Gestational Diabetes
}

\section{Citation}

Dishi, Michal, Karin Hevner, Chunfang Qiu, Neway G. Fida, Dejene F. Abetew, Michelle A. Williams, and Daniel A. Enquobahrie. 2016. "Early Pregnancy Maternal Hepatocyte Growth Factor and Risk of Gestational Diabetes." British journal of medicine and medical research 9 (1): BJMMR.18632. doi:10.9734/BJMMR/2015/18632. http://dx.doi.org/10.9734/BJMMR/2015/18632.

\section{Published Version}

doi:10.9734/BJMMR/2015/18632

\section{Permanent link}

http://nrs.harvard.edu/urn-3:HUL.InstRepos:27320401

\section{Terms of Use}

This article was downloaded from Harvard University's DASH repository, and is made available under the terms and conditions applicable to Other Posted Material, as set forth at http:// nrs.harvard.edu/urn-3:HUL.InstRepos:dash.current.terms-of-use\#LAA

\section{Share Your Story}

The Harvard community has made this article openly available.

Please share how this access benefits you. Submit a story.

\section{Accessibility}




\title{
Early Pregnancy Maternal Hepatocyte Growth Factor and Risk of Gestational Diabetes
}

\author{
Michal Dishi ${ }^{1,{ }^{*}}$, Karin Hevner ${ }^{1}$, Chunfang Qiu ${ }^{1}$, Neway G. Fida ${ }^{1,2}$, Dejene F. Abetew ${ }^{1}$, \\ Michelle A. Williams ${ }^{3}$, and Daniel A. Enquobahrie ${ }^{1,2}$ \\ ${ }^{1}$ Center for Perinatal Studies, Swedish Medical Center, Seattle, WA, USA \\ ${ }^{2}$ Department of Epidemiology, University of Washington, Seattle, WA, USA \\ ${ }^{3}$ Department of Epidemiology, Harvard School of Public Health, Boston, MA, USA
}

\begin{abstract}
Aims-We investigated associations of serum hepatocyte growth factor (HGF) with risk of gestational diabetes mellitus (GDM). We also examined whether pre-pregnancy overweight/ obesity status or leisure-time physical activity (LTPA) modify these associations.
\end{abstract}

Methods-In a nested case-control study (173 GDM cases and 187 controls) among participants of a pregnancy cohort, early pregnancy (16 weeks of gestation, on average) serum HGF was measured using enzyme-linked immunoassay. GDM was diagnosed using American Diabetes Association guidelines. Logistic regression was used to calculate odd ratios (ORs) and 95\% confidence intervals (CI). Effect modifications by pre-pregnancy overweight/obesity status or LTPA during pregnancy were examined using stratified analyses and interaction terms.

Results-Overall, we did not find significant associations of serum HGF with GDM risk (pvalue $>0.05$ ). However, compared with women who had low serum HGF concentrations ( $<2.29 \mathrm{ng} /$ $\mathrm{ml}$ ), women with high serum HGF concentrations ( $\geq 2.29 \mathrm{ng} / \mathrm{ml}$ ) had 3.8-fold (95\%CI: 1.30 10.98 ) and 4.5-fold (95\%CI: 1.28-15.80) higher GDM risk among women who were overweight/ obese, pre-pregnancy (body mass index $25 \mathrm{~kg} / \mathrm{m}^{2}$ ), or did not report LTPA, respectively. These

\footnotetext{
This is an Open Access article distributed under the terms of the Creative Commons Attribution License (http://creativecommons.org/ licenses/by/4.0), which permits unrestricted use, distribution, and reproduction in any medium, provided the original work is properly cited.

${ }^{*}$ Corresponding author: michal.dishi@gmail.com.

Authors' contributions

This work was carried out in collaboration between all authors. Author MD contributed to study conception, study design, and manuscript write-up. Author KH carried out the experiments and reviewed manuscript. Author CQ performed statistical analyses and edited the manuscript. Authors NGF and DFA participated in the study design and edited the manuscript. Author MAW PI of the Omega study, contributed to conception and study design, and edited the manuscript. Author DAE contributed to conception, study design, and manuscript write-up. All authors read and approved the final manuscript.
}

CONSENT

All participants provided written informed consent.

ETHICAL APPROVAL

The procedures used in this study were approved by the Institutional Review Boards of the Swedish Medical Center and Tacoma General Hospital, WA.

COMPETING INTERESTS

None of the authors have any financial or non-financials conflicts of interest in the area of the research presented in this manuscript. 
associations were not present among women who were not overweight/obese (interaction $\mathrm{p}=0.05$ ) or reported LTPA (interaction $\mathrm{p}=0.05$ ).

Conclusion-Overweight/obesity status and LTPA may modify associations of early pregnancy serum HGF with subsequent GDM risk.

\section{Keywords}

Hepatocyte growth factor; gestational diabetes mellitus; obesity; physical activity

\section{INTRODUCTION}

Gestational diabetes mellitus (GDM), a pregnancy-related disorder of glucose metabolism, complicates between 5-7\% of all pregnancies [1-3]. GDM is associated with adverse fetal outcomes such as macrosomia and birth trauma. In addition, women with GDM represent a group of pregnant women with significant risk for developing glucose intolerance later in life [4,5]. Insulin resistance and reduced insulin secretion are known to be the central disturbances in the pathogenesis of GDM, similar to Type 2 diabetes. A variety of predisposing factors have been associated with GDM risk (including advanced maternal age, pre-pregnancy overweight and obesity status, and reduced physical activity) [6-11]. However, a significant gap remains in our understanding of risk factors and mediating mechanisms that contribute to GDM. Importantly, few prospective studies evaluated biomarkers that are associated with subsequent risk of GDM, limiting opportunities for prevention and early identification of women with higher risk for GDM.

Hepatocyte growth factor (HGF) is a mesenchymal-derived pleiotropic factor that regulates cellular growth and morphogenesis, as well as tissue regeneration and repair [12,13]. In experimental studies, investigators demonstrated that HGF plays a key role in pancreatic islet cell mass increase (and hyperinsulinemia), and insulin signaling in the liver [14]. Disruption of HGF and its receptor signaling enhanced pancreatic beta-cell death, and accelerated onset of Type 2 diabetes [15]. In humans, higher serum HGF concentrations were associated with both newly diagnosed and long-standing Type 1 diabetes [13], insulin resistance, and prevalent Type 2 diabetes [16]. The only previous study to examine relationships between HGF and GDM was an experimental study that reported that HGF/cMet signaling is essential for maternal beta-cell adaptation during pregnancy and its absence/attenuation leads to GDM [17]. However, to our knowledge, association of circulating HGF with GDM has not been investigated in humans. Based on available literature, we hypothesized that HGF concentrations are positively associated with risk of GDM, and, that these associations will be stronger among women who also have additional risk factors of abnormal glucose metabolism (such as GDM) including obesity [18] and physical activity [19] that have been related to HGF.

Therefore, we investigated associations of early pregnancy HGF concentration with risk of GDM in a pregnancy cohort. We also examined whether these associations are modified by pre-pregnancy overweight/obesity status or leisure-time physical activity (LTPA) during pregnancy. 


\section{METHODS}

The study population for this nested case - control study was drawn from participants of the Omega study. The Omega study is a prospective cohort study designed to examine maternal dietary and lifestyle risk factors of preeclampsia, GDM and other adverse pregnancy outcomes [20,21]. The study population comprised of women attending prenatal care clinics affiliated with Swedish Medical Center and Tacoma General Hospital, in Seattle, WA and Tacoma, WA, respectively. Women eligible for inclusion into the study were those who initiated prenatal care prior to 16 week of gestation. Women were ineligible if they were younger than 18 years of age, did not speak and read English, did not plan to carry the pregnancy to term, or did not plan to deliver at either of the two research hospitals. The procedures used in this study were approved by the Institutional Review Boards of the Swedish Medical Center and Tacoma General Hospital, WA. All participants provided written informed consent.

Participants were invited to participate in an in-person interview and provided blood and urine samples at or shortly after enrollment [16 weeks of gestation, on average). After delivery, maternal and infant records were reviewed for information on course and outcomes of pregnancy. From structured questionnaires and medical records, we obtained information on maternal socio-demographic characteristics, life style habits (such as leisure-time physical activity during pregnancy), family medical history, and reproductive and medical histories. Body mass index (BMI) was calculated as weight (in kilograms) divided by height (in meters) squared. Pre-pregnancy overweight/obesity status was defined as pre-pregnancy BMI $\geq 25 \mathrm{~kg} / \mathrm{m} 2$.

GDM cases and controls were selected from pregnant women who enrolled in the Omega Study between 1996 and 2006. During this period, 5,063 eligible women were approached and 4,000 (approximately 79\%) agreed to participate. A total of 3,886 pregnant women provided blood samples and completed interviews. The diagnosis of GDM was made using the American Diabetes Association 2004 guidelines [1]. In our study settings, all attendants of perinatal care clinics are screened at 24-28 weeks gestation using a 1-hour oral glucose load $(50 \mathrm{~g})$ screening test. Women who have post- load glucose concentrations $>140 \mathrm{mg} / \mathrm{dl}$ were then followed-up within 1-2 weeks with a 3-hour oral glucose $(100 \mathrm{~g})$ tolerance test. Women were diagnosed with GDM if two or more of the four diagnostic glucose concentration measurements met or exceeded the following: fasting $\geq 95 \mathrm{mg} / \mathrm{dl} ; 1$ hour postchallenge $\geq 180 \mathrm{mg} / \mathrm{dl} ; 2$ hour post-challenge $\geq 155 \mathrm{mg} / \mathrm{dl}$; and, 3 hour post-challenge $\geq 140$ $\mathrm{mg} / \mathrm{dl}$. Among Omega study participants, we identified and sampled all 191 women who developed GDM. We also randomly sampled 191 control women who did not develop GDM. None of the GDM cases or selected controls had pre-gestational diabetes mellitus. There were 18 GDM cases and 4 controls that did not have adequate serum samples for serum HGF measurements. The final analytic population included 173 GDM cases and 187 controls.

Maternal serum HGF in early pregnancy (16 week of gestation, on average) was determined using commercially available HGF enzyme-linked immunoassay (Quantikine Human HGF ELISA R\&D Systems Cat\# DHG00 Minneapolis, MN, USA) according to the 
manufacturer's recommendations. All assays were performed by one technician who was blinded to the case control status of study participants. The Inter-and Intra-assay coefficients of variations for the measurements were $<10 \%$.

\section{STATISTICAL ANALYSIS}

We examined distribution of selected maternal characteristics among GDM cases and controls. Statistically significant differences between the groups were evaluated using Student $\mathrm{t}$ test $\mathrm{p}$-values for continuous variables and chi square test $\mathrm{p}$-values for categorical variables.

Unadjusted and adjusted logistic regression models were used to examine associations of serum HGF concentrations with risk of GDM. Adjusted models included a priori identified potential confounders and variables that altered unadjusted regression estimates by $10 \%$ or more. Final adjusted models included covariates for maternal age, race/ethnicity, family history of diabetes, pre-pregnancy BMI, and leisure-time physical activity during the pregnancy. Serum HGF was assessed both as a continuous and categorical (quartiles, using the lowest quartile as the referent) variable. Cut-offs for quartiles of early pregnancy serum HGF concentrations were determined based on HGF measurement values among controls. Regression models were used to compute unadjusted and adjusted odds ratios (ORs/aORs) and corresponding $95 \%$ confidence intervals (CIs). P-value for trend was computed by assessing linear trend across increasing quartiles of serum HGF concentrations.

We evaluated our hypotheses of interactions between serum HGF concentrations and prepregnancy overweight/obesity status or leisure-time physical activity (LTPA) during early pregnancy on GDM risk using stratified models and interaction terms as follows. In stratified analyses, we examined whether associations of high/low serum HGF concentrations (using the median, $\geq 2.29 \mathrm{ng} / \mathrm{ml}$, as cut-off) with GDM risk differ among strata that were defined by either pre-pregnancy overweight/obesity (BMI $\geq 25 \mathrm{~kg} / \mathrm{m} 2$ ) status or LTPA (active/not active) status. We also assessed whether the joint associations of serum HGF concentrations and pre-pregnancy overweight/obesity status with risk of GDM was greater than expected given potential independent associations. For this analyses, we created a variable that categorized women as (1) $\mathrm{HGF}<2.29 \mathrm{ng} / \mathrm{ml}$ and $\mathrm{BMI}<25 \mathrm{~kg} / \mathrm{m} 2$, (2) $\mathrm{HGF} \geq 2.29 \mathrm{ng} / \mathrm{ml}$ and $\mathrm{BMI}<25$ $\mathrm{kg} / \mathrm{m} 2$, (3) $\mathrm{HGF}<2.29 \mathrm{ng} / \mathrm{ml}$ and $\mathrm{BMI} \geq 25 \mathrm{~kg} / \mathrm{m} 2$, or (4) HGF $\geq 2.29 \mathrm{ng} / \mathrm{ml}$ and BMI $\geq 25$ $\mathrm{kg} / \mathrm{m} 2$. An analogous variable was created to assess joint associations of serum HGF concentrations and LTPA with GDM risk. Statistical significance of interactions was determined by evaluating p-values of interaction terms between high/low serum HGF and either pre-pregnancy overweight/obesity status or LTPA (active/not active) status in respective multivariable logistic regression models.

All analyses were conducted using SPSS (version 18) statistical software. Statistical significance was defined as two-sided $\mathrm{p}<0.05$.

\section{RESULTS}

Selected study participant characteristics are shown in Table 1. GDM cases were older and had higher pre-pregnancy BMI compared with controls (mean age 34.2 vs. 33.0 years and 
pre-pregnancy BMI 26.6 vs. $23.4 \mathrm{~kg} / \mathrm{m}^{2}$ for GDM cases and controls, respectively). GDM cases were also more likely to report a positive history of hypertension, family history of diabetes, or a family history of hypertension compared with controls (all p-values $<0.05$ ). Controls were more likely to be non-Hispanic White compared with GDM cases (86\% vs. $70.5 \%$, respectively). Mean serum HGF concentrations were $2.02 \mathrm{ng} / \mathrm{ml}$ and $1.95 \mathrm{ng} / \mathrm{ml}$ among GDM cases and controls, respectively ( $\mathrm{p}$-value $=0.28$ ).

Overall, we did not find significant associations of serum HGF concentrations with GDM risk when serum HGF was modeled as a continuous ( $\mathrm{p}$-value $=0.361$ ) or categorical variable (quartile trend $p$-value $=0.479$ ) (Table 2). A statistically insignificant 1.2-fold increase in GDM risk was observed among women who were in the highest quartile for serum HGF when compared with women in the referent (lowest) quartile for serum HGF (Adj. OR: 1.22 95\%CI: 0.65-2.28).

In stratified analyses, associations of serum HGF concentrations with GDM risk was observed among women who were overweight/obese, pre-pregnancy (Table 3). Compared with women who had low serum HGF concentrations ( $<2.29 \mathrm{ng} / \mathrm{ml})$, women with high serum HGF concentrations ( $\geq 2.29 \mathrm{ng} / \mathrm{ml}$ ) had 3.8-fold (95\%CI: 1.30-10.98) higher GDM risk among women who were overweight/obese. Similar high serum HGF-related increase in GDM risk was not observed among non-overweight/obese women (Adj. OR: 1.12, 95\%CI: 0.61-2.04). Women who had high serum HGF and were overweight/obese had a 7-fold (95\%CI: 2.58-18.54) higher risk of GDM compared with women who had low serum HGF and were not overweight/obese ( $\mathrm{p}$-value for interaction $=0.05$ ).

Similarly, associations of serum HGF concentrations with GDM risk were observed among women who did not report LTPA during current pregnancy (Table 4). Compared with women who had low serum HGF concentrations ( $<2.29 \mathrm{ng} / \mathrm{ml}$ ), women with high serum HGF concentrations ( $\geq 2.29 \mathrm{ng} / \mathrm{ml}$ ) had statistically significant higher GDM risk among women who were inactive (Adj. OR:4.50, 95\%CI:1.28-15.80) but not among women who were active (Adj. OR:1.17, 95\%CI:0.66-2.06). Women who had high serum HGF and were inactive had a 2.7-fold (95\%CI:1.04-6.94) higher risk of GDM compared with women who had low serum HGF concentrations and were active (interaction p-value 0.046).

\section{DISCUSSION}

In the current study, we did not find overall statistically significant associations between early pregnancy serum HGF concentrations and GDM risk. However, we found that prepregnancy overweight/obesity status and LTPA modify associations of early pregnancy HGF with subsequent GDM risk. Increased serum HGF related risk of subsequent GDM was observed only among women who overweight/obese during pre-pregnancy or did not report LTPA during the pregnancy (p-values for interactions 0.05 and 0.046 , respectively).

Previous studies have reported potential associations of higher serum HGF concentrations and increased type 2 diabetes risk. For instance, in the study among post-menopausal women, participants in the highest tertile for serum HGF concentrations had a 2.4-fold (95\% CI1.12-5.47) higher risk for prevalent diabetes compared with participants in the lowest 
tertile for serum HGF concentrations [16]. Satani et al. [22] reported that mean serum HGF concentrations of patients with type 2 diabetes mellitus was $895 \mathrm{pg} / \mathrm{ml}$ (standard deviation $408 \mathrm{pg} / \mathrm{ml})$, a level considerably higher than the normal range $(<265 \mathrm{pg} / \mathrm{ml})$.

To our knowledge, the only study that investigated serum HGF concentrations and GDM risk was an experimental study conducted by Demirci et al [17]. In that study, researchers investigated the role of HGF in the maternal beta cell adaption during pregnancy in lab mice by knocking out the receptor of HGF, c-met, from islet cells. In the knock-out pregnant mice, beta cell mass was decreased and this was accompanied by increased blood glucose, decreased plasma insulin and impaired glucose tolerance, hallmarks of GDM [17].

These findings are in line with experimental investigations of Garacia-Ocana and his colleagues who found that HGF increases beta cell mass in vivo [23]. In another recent experimental study to investigate a possible cause-effect relationship between increase in circulating HGF levels and compensatory islet hyperplasia / hyperinsulinemia, a strong correlation between HGF and the compensatory mechanism was demonstrated in three animal models of insulin resistance [14]. HGF increased beta cell mass in a dose-dependent manner; blocking HGF shuts down the compensatory mechanisms; and increases in HGF levels preceded the compensatory response associated with insulin resistance [14].

Overall evidence from previous studies indicate that HGF level increases in metabolic syndrome [24] and that HGF plays a role in insulin resistance and the development of T2DM. However, in our study we found that associations of higher early pregnancy serum HGF concentrations with risk of GDM were limited to women who were overweight/obese, pre-pregnancy, or who did not report LTPA. Our findings highlight the potential importance of complex relationships of HGF levels with other GDM risk factors in human populations.

Several studies have reported associations of higher HGF levels with adiposity markers. Circulating levels of HGF were elevated (up to threefold) among obese individuals compared with lean individuals $(\mathrm{p}<0.0001)$ [18]. Since pre-pregnancy obesity is a risk factor to GDM, we can contemplate that associations of higher HGF levels with risk of GDM may be exaggerated in the setting of pre-pregnancy obesity, as observed in the current study. Whether HGF mediates associations of pre-pregnancy BMI with risk of GDM is a potential area of future investigations.

Associations of physical activity and inactivity during pregnancy on the risk for GDM have been reported in previous studies [10,25]. Physical activity, especially vigorous activity before pregnancy and at least light to moderate activity during pregnancy, may reduce risk for abnormal glucose tolerance and GDM [26]. In a meta-analysis that reviewed the current evidence on the relationship between physical activity and GDM risk, Tobias et al. [25] reported that higher levels of physical activity before pregnancy or in early pregnancy are associated with significantly lower risk of developing GDM. The mechanisms that increased physical activity may cause reduction in the risk of GDM are multifaceted. Research among non-pregnant women indicates exercise-induced physical activity related improvement in glycemic control [27] that involves increased insulin-mediated and noninsulin mediated glucose disposal [28]. Some of the non-insulin mediated glycemic control may be accounted 
for by decreased oxidative stress, decreased fat mass, and increases in muscle mass [27]. Other studies have also shown that exercise has anti-inflammatory effects that may improve insulin sensitivity [29,30]. In our study, associations of higher HGF concentration with increased GDM risk was observed only among women who reported no LTPA. One potential reason for this observation may be that women with no LTPA have a lower "reserve" in glucose control and are more likely to be affected by higher HGF levels. The relationships between HGF and physical activity are less clear and it is not known whether HGF potentially mediates associations of physical activity with risk of GDM.

Several strengths of our study deserve mention. To our knowledge, this is the first population study to investigate associations of HGF with risk of GDM. The prospective design of the study helps clarify temporal relationships. We used strict criteria for GDM diagnosis, minimizing misclassification. Our study population is a well-characterized pregnancy cohort and the extensive data collection allowed us to control for several potential confounders.

Several potential limitations should be considered when interpreting our results. Although we adjusted for several potential confounders, we cannot exclude the possibility of residual confounding or confounding by unmeasured variables. We used self-report LTPA to characterize habitual physical activity in early pregnancy which is prone to some misclassification. However, because of the prospective study design, misclassification is not conditional on pregnancy outcome (GDM status). We used a single measurement of early pregnancy HGF and thus cannot definitively comment on pre-pregnancy HGF levels. This would limit our assessment of the relationships between HGF and the modifying GDM risk factors we evaluated (pre-pregnancy obesity and LTPA). Previous studies have used both serum and plasma to measure HGF. Available evidence does not indicate potential differences in HGF-GDM associations dependent on whether HGF is measured in serum $[13,17,18]$ or plasma $[14,16]$. However, the relevance of our findings to plasma HGF measurements needs further exploration. Finally, generalizability of our findings may be limited because our study participants were predominantly non-Hispanic white and residents of the pacific northwestern region of the USA.

\section{CONCLUSION}

Pre-pregnancy overweight/obesity status and LTPA may modify associations of early pregnancy HGF with subsequent GDM risk. Our findings enhance understanding of GDM pathogenesis and relationships between risk factors in human populations. Further, our findings support consideration of early pregnancy serum HGF as a biomarker of subsequent GDM for preventative and diagnostic purposes, particularly among overweight/obese or physically inactive women. Future replication and mechanistic studies of observed interactions are warranted.

\section{Acknowledgments}

This research was supported by awards from the National Institute of Health (R01HD-055566 and R01HD-32562). Dr. Enquobahrie was supported by grant from the National Institute of Health (K01HL-103184). The authors are indebted to participants of the Omega study and staff of center for perinatal studies, Swedish Medical Center, Seattle, WA. 


\section{ABBREVIATIONS}

$\begin{array}{ll}\text { HGF } & \text { Hepatocyte growth factor } \\ \text { GDM } & \text { Gestational diabetes mellitus } \\ \text { LTPA } & \text { Leisure-time physical activity } \\ \text { CI } & \text { Confident interval } \\ \text { OR } & \text { Odd ratio } \\ \text { BMI } & \text { Body mass index }\end{array}$

\section{REFERENCES}

1. American Diabetes Association: Gestational diabetes mellitus. Diabetes Care. 2004; 27(Suppl.1): 88-90.

2. Expert Committee on the Diagnosis and Classification of Diabetes Mellitus. Report of the expert committee on the diagnosis and classification of diabetes mellitus. Diabetes Care. 2003; 26(Suppl 1):5-20.

3. Landon MB, Gabbe SG. Gestational diabetes mellitus. Obstet Gynecol. 2011; 118(6):1379-1393. [PubMed: 22105269]

4. Bellamy L, Casas JP, Hingorani AD, Williams D. Type 2 diabetes mellitus after gestational diabetes: A systematic review and meta-analysis. Lancet. 2009; 373(9677):1773-1779. [PubMed: 19465232]

5. Ben-Haroush A, Yogev Y, Hod M. Epidemiology of gestational diabetes mellitus and its association with Type 2 diabetes. Diabet Med. 2004; 21(2):103-113. [PubMed: 14984444]

6. Retnakaran R, Connelly PW, Sermer M, Zinman B, Hanley AJ. The impact of family history of diabetes on risk factors for gestational diabetes. Clin Endocrinol (Oxf). 2007; 67(5):754-760. Epub 2007 Jul 3. [PubMed: 17608815]

7. Hedderson MM, Williams MA, Holt VL, Weiss NS, Ferrara A. Body mass index and weight gain prior to pregnancy and risk of gestational diabetes mellitus. Am J Obstet Gynecol. 2008; 198(4): 409.e1-409.e7. [PubMed: 18068138]

8. Dishi M, Enquobahrie DA, Abetew DF, Qiu C, Rudra CB, Williams MA. Age at menarche, menstrual cycle characteristics and risk of Gestational diabetes. Diabetes Res Clin Pract. 2011; 93:437-442. [PubMed: 21816498]

9. Dempsey JC, Butler CL, Sorensen TK, Lee IM, Thompson ML, Miller RS, Frederick IO, Williams MA. A case-control study of maternal recreational physical activity and risk of gestational diabetes mellitus. Diabetes Res Clin Pract. 2004; 66(2):203-215. [PubMed: 15533588]

10. Dempsey JC, Butler CL, Williams MA. No need for a pregnant pause: Physical activity may reduce the occurrence of gestational diabetes mellitus and preeclampsia. Exerc Sport Sci Rev. 2005; 33(3):141-149. [PubMed: 16006822]

11. Rudra CB, Sorensen TK, Leisenring WM, Dashow E, Williams MA. Weight characteristics and height in relation to risk of gestational diabetes mellitus. Am J Epidemiol. 2007; 165(3):302-308. [PubMed: 17074967]

12. Zarnegar R, Michalopoulos GK. The many faces of hepatocyte growth factor: From hepatopoiesis to hematopoiesis. J Cell Biol. 1995; 129:1177-1180. [PubMed: 7775566]

13. Kulseng B, Børset M, Espevik T, Sundan A. Elevated hepatocyte growth factor in sera from patients with insulin-dependent diabetes mellitus. Acta Diabetol. 1998; 35(2):77-80. [PubMed: 9747958]

14. Araújo TG, Oliveira AG, Carvalho BM, Guadagnini D, Protzek AO, Carvalheira JB, Boschero AC, Saad MJ. Hepatocyte growth factor plays a key role in insulin resistance-associated compensatory mechanisms. Endocrinology. 2012; 153(12):5760-5769. [PubMed: 23024263]

15. Mellado-Gil J, Rosa TC, Demirci C, Gonzalez-Pertusa JA, Velazquez-Garcia S, Ernst S, Valle S, Vasavada RC, Stewart AF, Alonso LC, Garcia-Ocaña A. Disruption of hepatocyte growth factor/c- 
Met signaling enhances pancreatic beta-cell death and accelerates the onset of diabetes. Diabetes. 2011; 60(2):525-536. [PubMed: 20980460]

16. Rajpathak SN, Wassertheil-Smoller S, Crandall J, Liu S, Ho GY. Hepatocyte growth factor and clinical diabetes in postmenopausal women. Diabetes Care. 2010; 33(9):2013-2015. [PubMed: 20519660]

17. Demirci C, Ernst S, Alvarez-Perez JC, Rosa T, Valle S, Shridhar V, Casinelli GP, Alonso LC, Vasavada RC, García-Ocana A. Loss of HGF/c-Met signaling in pancreatic $\beta$-cells leads to incomplete maternal $\beta$-cell adaptation and gestational diabetes mellitus. Diabetes. 2012; 61(5): 1143-1152. [PubMed: 22427375]

18. Rehman J, Considine RV, Bovenkerk JE, Li J, Slavens CA, Jones RM, March KL. Obesity is associated with increased levels of circulating hepatocyte growth factor. J Am Coll Cardiol. 2003; 41(8):1408-1413. 16. [PubMed: 12706940]

19. Yasuda S, Goto Y, Takaki H, Asaumi Y, Baba T, Miyazaki S, Nonogi H. Exercise-induced hepatocyte growth factor production in patients after acute myocardial infarction: Its relationship to exercise capacity and brain natriuretic peptide levels. Circ J. 2004; 68(4):304-307. [PubMed: 15056825]

20. Enquobahrie DA, Williams MA, Butler CL, Frederick IO, Miller RS, Luthy DA. Maternal plasma lipid concentrations in early pregnancy and risk of preeclampsia. Am J Hypertens. 2004; 17(7): 574-581. [PubMed: 15233976]

21. Abetew DF, Enquobahrie DA, Dishi M, Rudra CB, Miller RS, Williams MA. Age at menarche, menstrual characteristics, and risk of preeclampsia. ISRN Obstet Gynecol. 2011; 2011:472083. [PubMed: 22263114]

22. Satani K, Konya H, Hamaguchi T, Umehara A, Katsuno T, Ishikawa T, Kohri K, Hasegawa Y, Suehiro A, Kakishita E, Namba M. Clinical significance of circulating hepatocyte growth factor, a new risk marker of carotid atherosclerosis in patients with Type 2 diabetes. Diabet Med. 2006; 23(6):617-622. [PubMed: 16759302]

23. Garcia-Ocaña A, Takane KK, Syed MA, Philbrick WM, Vasavada RC, Stewart AF. Hepatocyte growth factor overexpression in the islet of transgenic mice increases beta cell proliferation, enhances islet mass, and induces mild hypoglycemia. J Biol Chem. 2000; 275(2):1226-1232. [PubMed: 10625667]

24. Hiratsuka A, Adachi H, Fujiura Y, Yamagish S, Hirai Y, Enomoto M, Satoh A, Hino A, Furuki k, Imaizumi T. Strong association between serum hepatocyte growth factor and metabolic syndrome. J Clin Endocrinl Metab. 2005; 90:2927-2931.

25. Tobias DK, Zhang C, van Dam RM, Bowers K, Hu FB. Physical activity before and during pregnancy and risk of gestational diabetes mellitus: A meta-analysis. Diabetes Care. 2011; 34(1): 223-229. [PubMed: 20876206]

26. Oken E, Ning Y, Rifas-Shiman SL, Radesky JS, Rich-Edwards JW, Gillman MW. Associations of physical activity and inactivity before and during pregnancy with glucose tolerance. Obstet Gynecol. 2006; 108(5):1200-1207. [PubMed: 17077243]

27. Hu FB, Manson JE, Stampfer MJ, Colditz G, Liu S, Solomon CG, Willett WC. Diet, lifestyle, and the risk of type 2 diabetes mellitus in women. N Engl J Med. 2001; 345(11):790-797. [PubMed: 11556298]

28. Devlin JT. Effects of exercise on insulin sensitivity in humans. Diabetes Care. 1992; 15(11):16901693. [PubMed: 1468302]

29. Bradley RL, Jeon JY, Liu FF, Maratos-Flier E. Voluntary exercise improves insulin sensitivity and adipose tissue inflammation in diet-induced obese mice. Am J Physiol Endocrinol Metab. 2008; 295(3):586-594.

30. Bruun JM, Helge JW, Richelsen B, Stallknecht B. Diet and exercise reduce low-grade inflammation and macrophage infiltration in adipose tissue but not in skeletal muscle in severely obese subjects. Am J Physiol Endocrinol Metab. 2006; 290(5):961-967. Epub 2005 Dec 13. 


\section{을 \\ 골}

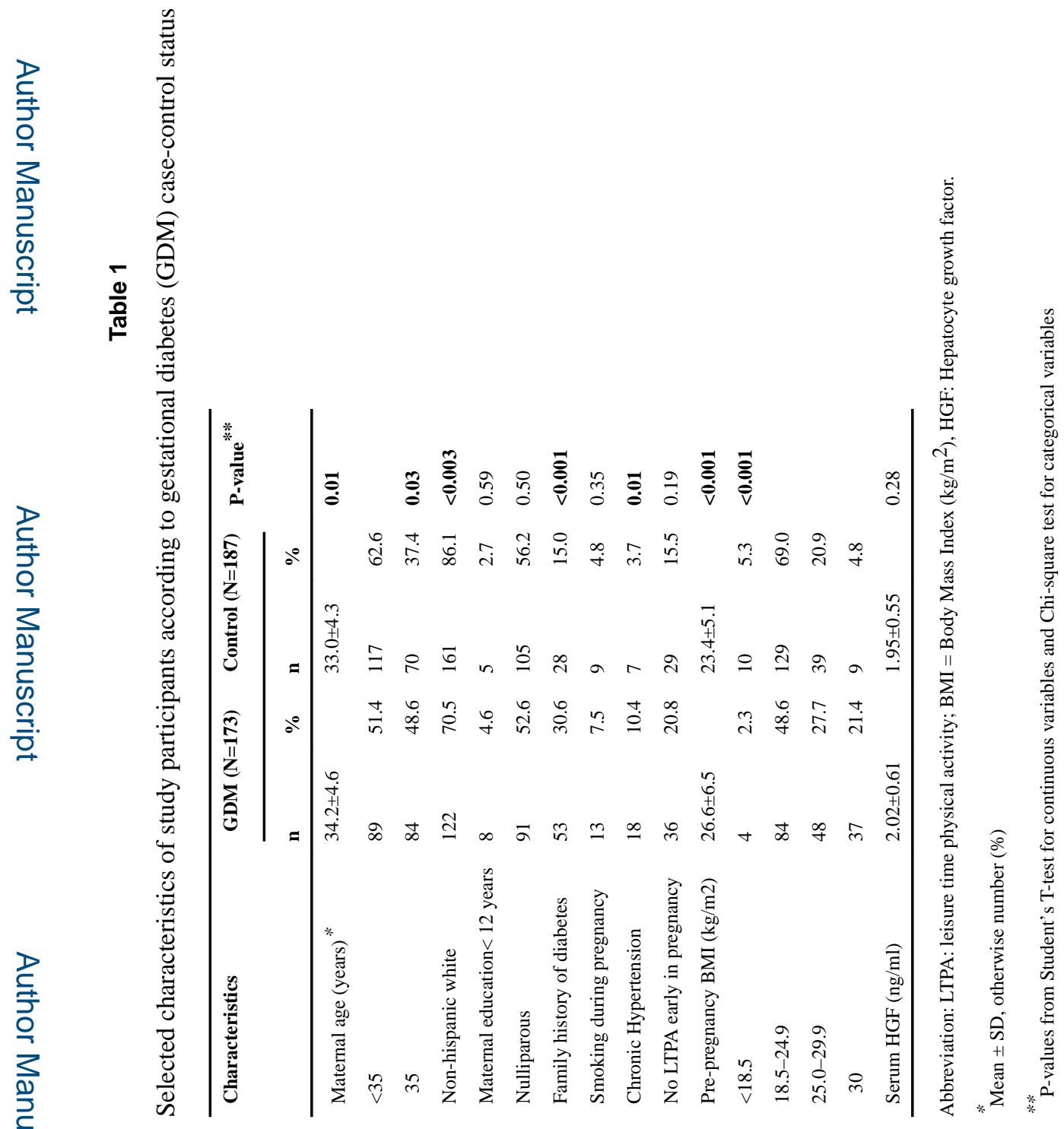


Table 2

Risk of gestational diabetes (GDM) according to maternal serum hepatocyte growth factor (HGF) concentrations in early pregnancy

\begin{tabular}{lllll}
\hline $\begin{array}{l}\text { Serum HGF (ng/ml) } \\
\text { concentrations }\end{array}$ & $\begin{array}{l}\text { GDM cases } \\
(\mathbf{N = ~ 1 7 3 )}\end{array}$ & $\begin{array}{l}\text { Controls } \\
(\mathbf{N = 1 8 7})\end{array}$ & $\begin{array}{l}\text { Unadjusted } \\
\text { OR }(\mathbf{9 5 \%} \mathbf{C I})\end{array}$ & $\begin{array}{l}\text { Adjusted } \\
\text { OR (95\% CI) }\end{array}$ \\
\hline Continuous & ------ & ----- & $1.22(0.85-1.74)$ & $1.20(0.81-1.77)$ \\
Categorical & $\mathrm{N}(\%)$ & $\mathrm{N}(\%)$ & & \\
Quartile 1 (<1.6) & $41(23.7)$ & $46(24.6)$ & $1.00($ referent $)$ & $1.00($ referent $)$ \\
Quartile 2 $(1.62-1.95)$ & $37(21.4)$ & $46(24.6)$ & $0.90(0.49-1.66)$ & $0.72(0.37-1.41)$ \\
Quartile 3 $(1.96-2.28)$ & $42(24.3)$ & $47(25.1)$ & $1.00(0.55-1.81)$ & $0.75(0.39-1.43)$ \\
Quartile 4 ( $\geq 2.29)$ & $53(30.6)$ & $48(25.7)$ & $1.24(0.70-2.20)$ & $1.22(0.65-2.28)$ \\
P-value for trend & & & 0.405 & 0.479 \\
\hline
\end{tabular}

* Adjusted for maternal age, race/ethnicity, and family history of diabetes, pre-pregnancy BMI, and leisure time physical activity during the pregnancy 


\section{Table 3}

Interactions of maternal serum hepatocyte growth factor (HGF) with pre-preganncy overweight/obesity status on risk of gestational diabetes (GDM)

\begin{tabular}{|c|c|c|c|c|}
\hline \multirow[t]{2}{*}{$\begin{array}{l}\text { High HGF concentrations \& } \\
\text { pre-pregnancy } \text { BMI }^{*}\end{array}$} & \multirow[t]{2}{*}{$\begin{array}{l}\text { GDM cases } \\
(\mathbf{N}=173)\end{array}$} & \multirow[t]{2}{*}{$\begin{array}{l}\text { Controls } \\
(\mathrm{N}=187)\end{array}$} & \multirow[t]{2}{*}{$\begin{array}{l}\text { Stratified model } \\
\text { OR }(95 \% \mathrm{CI})\end{array}$} & \multirow[t]{2}{*}{$\begin{array}{l}\text { Joint model } \\
\text { OR }(95 \% \text { CI })\end{array}$} \\
\hline & & & & \\
\hline $\mathrm{HGF}<2.29 \mathrm{ng} / \mathrm{ml} \&<25 \mathrm{~kg} / \mathrm{m}^{2}$ & $61(35.5)$ & $97(51.9)$ & 1.00 (referent) & 1.00 (referent) \\
\hline HGF $\geq 2.29 \mathrm{ng} / \mathrm{ml} \&<25 \mathrm{~kg} / \mathrm{m}^{2}$ & $27(15.7)$ & $42(22.5)$ & $1.12(0.61-2.04)$ & $1.08(0.59-1.98)$ \\
\hline $\mathrm{HGF}<2.29 \mathrm{ng} / \mathrm{ml} \& \geq 25 \mathrm{~kg} / \mathrm{m}^{2}$ & $58(33.7)$ & $42(22.5)$ & 1.00 (referent) & $1.96(1.15-3.34)$ \\
\hline $\mathrm{HGF} \geq 2.29 \mathrm{ng} / \mathrm{ml} \& \geq 25 \mathrm{~kg} / \mathrm{m}^{2}$ & $26(15.1)$ & $6(3.2)$ & $3.77(1.30-10.98)$ & $6.91(2.58-18.54)$ \\
\hline $\mathrm{P}$ for interaction term & & & & 0.050 \\
\hline
\end{tabular}

*Pre-pregnancy overweight/obesity status defined as pre-pregnancy BMI $\geq 25 \mathrm{~kg} / \mathrm{m}^{2}$.

All models adjusted for maternal race/ethnicity, family history of diabetes, and leisure time physical activity during pregnancy 


\section{Table 4}

Interactions of maternal serum hepatocyte growth factor (HGF) with leisure-time physical activity (LTPA) during the pregnancy on risk of gestational diabetes (GDM)

\begin{tabular}{|c|c|c|c|c|}
\hline \multirow[t]{2}{*}{$\begin{array}{l}\text { High HGF concentrations \& } \\
\text { LTPA }\end{array}$} & $\begin{array}{l}\text { GDM cases } \\
(\mathrm{N}=173)\end{array}$ & $\begin{array}{l}\text { Controls } \\
(\mathrm{N}=187)\end{array}$ & \multirow[t]{2}{*}{$\begin{array}{l}\text { Stratified model } \\
\text { OR }(95 \% \mathrm{CI})\end{array}$} & \multirow[t]{2}{*}{$\begin{array}{l}\text { Joint model } \\
\text { OR }(95 \% \mathrm{CI})\end{array}$} \\
\hline & $\mathbf{N}(\%)$ & $\mathbf{N}(\%)$ & & \\
\hline $\mathrm{HGF}<2.29 \mathrm{ng} / \mathrm{ml} \&$ active & $101(58.4)$ & $118(63.1)$ & 1.00 (referent) & 1.00 (referent) \\
\hline $\mathrm{HGF} \geq 2.29 \mathrm{ng} / \mathrm{ml} \&$ active & $36(20.8)$ & $40(21.4)$ & $1.17(0.66-2.06)$ & $1.16(0.66-2.03)$ \\
\hline $\mathrm{HGF}<2.29 \mathrm{ng} / \mathrm{ml} \&$ inactive & $19(11.0)$ & $21(11.2)$ & 1.00 (referent) & $0.63(0.29-1.36)$ \\
\hline $\mathrm{HGF} \geq 2.29 \mathrm{ng} / \mathrm{ml} \&$ inactive & $17(9.8)$ & $8(4.3)$ & $4.50(1.28-15.80)$ & $2.68(1.04-6.94)$ \\
\hline $\mathrm{P}$ for interaction term & & & & 0.046 \\
\hline
\end{tabular}

All models adjusted for maternal race/ethnicity, family history of diabetes, and pre-pregnancy BMI 